\title{
MODEL PREDIKSI ARUS KAS MASA DEPAN PADA EMITEN LQ45 YANG TERDAFTAR DI BURSA EFEK INDONESIA
}

\author{
MODEL PREDICTION OF FUTURE CASH FLOW IN THE ISSUER LQ45 LISTED IN \\ INDONESIA STOCK EXCHANGE
}

\author{
Yulianti \\ Nirsetyo Wahdi \\ Saifudin \\ Jurusan Akuntansi Fakultas Ekonomi Universitas Semarang
}

\begin{abstract}
ABSTRAK
Penelitian ini bertujuan untuk memprediksi arus kas masa depan melalui kemampuan laba bersih, arus kas, perubahan piutang dan perubahan hutang. Penelitian ini menggunakan komponen laba bersih, arus kas, perubahan piutang dan perubahan hutang sebagai variabel independen dan arus kas masa depan sebagai variabel dependen.

Penelitian ini meggunakan model regresi linier barganda untuk menguji kemampuan laba bersih, arus kas, perubahan piutang dan perubahan hutang dalam memprediksi arus kas masa depan. Jenis data yang digunakan adalah data sekunder dari perusahaan LQ 45 yang terdaftar di Bursa Efek Indonesia selama periode 2008-2012. Pengambilan sampel dilakukan secara purposive sampling dengan jumlah sampel 50 perusahaan.

Hasil penelitian ini menunjukkan bahwa laba bersih dan arus kas berpengaruh signifikan terhadap arus kas di masa depan, hasil ini sesuai dengan penelitian yang dilakukan oleh Dahler dan Febriyanto (2006). Variabel perubahan piutang dan perubahan hutang tidak berpengaruh signifikan terhadap arus kas di masa depan, hasil ini sesuai dengan penelitian yang dilakukan oleh Triyono (2011).
\end{abstract}

Kata kunci : laba bersih, arus kas, perubahan piutang, perubahan hutang, arus kas masa depan.

\begin{abstract}
This study aims to predict future cash flows through the ability of earnings, cash flows, changes in receivables and payables change. This study uses a component earnings, cash flows, changes in receivables and payables change as the independent variable and the future cash flows as the dependent variable.

This study uses multiple regression models to test examines ability of earnings, cash flows, changes in receivables and payables changes in predicting future cash flows. The type of data used are secondary data from LQ 45 listed companies in Indonesia Stock Exchange (IDX) during the period 2008-2012. Sampling was done by purposive sampling with a sample of 50 companies.

The result of this study showed that earnings and cash flow have significantly effect on the future cash flows, these results are consistent with research conducted by Dahler and Febriyanto (2006). Variable changes in receivables and payables change does not significantly effect on the future cash flows, these results are consistent with research conducted by Triyono (2011).
\end{abstract}

Keywords: earnings, cash flow, changes in receivables, payables changes, future cash flows. 


\section{PENDAHULUAN}

Kemampuan para pelaku ekonomi dalam memprediksi kondisi keuangan dimasa depan sangat diperlukan sebelum membuat suatu keputusan ekonomi. Melalui laporan keuangan perusahaan para investor dapat mengevaluasi dan menganalisi kinerja manajemen dan melakukan prediksi perolehan laba di masa depan. Selain itu investor juga dapat mengestimasi arus kas yang akan datang dengan laporan keuangan. Menurut Pernyataan Standar Akuntansi Keuangan Nomor 1 paragraf 5 (IAI : 2009), tujuan laporan keuangan adalah untuk menyediakan informasi yang menyangkut posisi keuangan, kinerja serta perubahan posisi keuangan suatu perusahaan yang bermanfaat bagi sejumlah besar pemakai dalam mengambil suatu keputusan.

Pada awalnya laporan keuangan terdiri dari neraca dan laporan laba rugi. Dalam FASB (Financial Accounting Standard Board) Statement no. 95 muncul Cash Flow Statement atau Laporan Arus Kas yang sudah harus diterapkan pada pelaporan tahun buku (Harahap, 2013, hal 118). Kartikahadi, dkk (2012) menjelaskan bahwa arus kas yang bersumber dari aktivitas operasi adalah arus kas yang paling penting untuk mengevaluasi kemampuan entitas dalam mengelola dan menghasilkan arus kas untuk membelanjai operasi perusahaan, melunasi liabilitas, membayar deviden serta melakukan investasi baru. Arus kas berguna untuk menilai kemampuan perusahaan dalam menghasilkan kas dan setara kas, menilai dan membandingkan nilai arus kas sekarang dengan nilai arus kas masa depan.

Fenomena yang ditemukan yaitu laba bersih PT Bukit Asam Tbk (PTBA) anjlok hingga $44 \%$ sepanjang semester pertama tahun ini dibanding laba bersih periode yang sama tahun sebelumnya.
Sepanjang paruh pertama 2013, perseroan mencatat penurunan laba sebesar $44 \%$ dari $\mathrm{Rp} 1,5$ triliun pada semester I tahun 2012 menjadi Rp 870,12 miliar di semester I 2013. Berdasarkan laporan keuangan yang dipublikasikan perseroan, Jumat (26/7) terungkap bahwa turunnya laba tersebut imbas dari menurunnya penjualan sebesar 6,12 persen dari $\mathrm{Rp}$ 5,79 triliun pada semester $\mathrm{I} / 2012$ menjadi Rp 5,43 triliun pada akhir Juni 2013. Sementara kas dan setara kas perseroan juga tercatat turun 44 persen dari $\mathrm{Rp} \mathrm{5,9} \mathrm{triliun} \mathrm{menjadi} \mathrm{Rp} \mathrm{3,3} \mathrm{triliun}$ pada akhir semester I 2013 (www.merdeka.com).

Nilai asset atau nilai perusahaan secara keseluruhan ditentukan oleh arus kas yang dihasilkan. Arus kas dan laba bersih memiliki hubungan yang cukup erat. Arus kas bersih merupakan penjumlahan dari laba bersih perusahaan, pendapatan non kas dan beban non kas. Selain itu, laba bersih dapat berpengaruh dalam memprediksi arus kas operasi di masa mendatang karena laba bersih bersifat akrual yang berasal dari laba sebelum pajak ditambah pendapatan lain seperti pendapatan bunga dan dikurangi dengan beban lain-lain seperti beban bunga dan beban pajak. Dimana pendapatan bunga yang diperoleh perusahaan berasal dari pokok pinjaman dan bunga. Namun ketika angsuran pokok pinjaman yang sebagian tersebut dibayar maka akan berdampak terhadap penerimaan bunga perusahaan dimasa yang akan datang sehingga meningkatnya kas operasi yang diperoleh perusahaan.

Dahler dan Febrianto (2006) telah melakukan pengujian kembali mengenai prediksi arus kas masa depan, mereka mengelompokan perusahaan yang melaporkan laba positif dan laba negatif. Berdasarkan hasil pengujian hipotesisnya menyatakan bahwa arus kas operasi tahun berjalan memiliki kemampuan yang lebih baik dibandingkan laba dalam mem- 
prediksi arus kas operasi masa depan baik untuk kelompok perusahaan berlaba positif maupun berlaba negatif. Hasil penelitian tersebut bertolak belakang dengan penelitian Meliana dan Titik Indrawati (2012), yang menemukan bahwa laba merupakan prediktor arus kas masa depan yang lebih baik dibandingkan dengan arus kas. Hasil penelitian ini juga menyimpulkan laba operasi dan arus kas dari aktivitas operasi memiliki kemampuan prediksi yang tinggi terhadap arus kas dari aktivitas operasi masa depan.

Hasil penelitian Yuwana dan Jogi (2014) menyimpulkan bahwa variabel laba bersih secara parsial memiliki kemampuan untuk memprediksi arus kas operasi masa depan. Demikian pula dengan variabel arus kas operasi secara parsial memiliki kemampuan untuk memprediksi arus kas masa depan. Sedangkan Ferra (2012) menguji kemampuan laba bersih, arus kas operasi dan rasio piutang untuk mempengaruhi arus kas mendatang perusahaan food and beverage. Hipotesisnya menyatakan bahwa variabel laba bersih dan arus kas operasi berpengaruh signifikan terhadap prediksi arus kas operasi masa depan sedangkan rasio piutang secara parsial berpengaruh signifikan terhadap arus kas operasi masa depan. Hasil penelitian ini memiliki hasil yang senada dengan penelitian Meliana Titik Indrawati (2012).

Triyono (2011) menguji dampak kualitas laba terhadap kemampuan prediksi laba, arus kas dan komponen akrual menemukan hasil bahwa hipotesis pertama laba dan arus kas operasi secara bersama tidak memiliki kemampuan lebih baik dalam memprediksi arus kas operasi masa depan. Untuk memperkuat prediksi akuntansi tersebut, maka variabel kualitas laba disediakan sebagai informasi tambahan. Dengan adanya tambahan informasi kualitas laba ditemukan hasil kualitas laba memperkuat kemampuan prediksi laba dan arus kas operasi dalam memprediksi arus kas operasi masa depan. Sedangkan untuk hipotesis kedua dapat disimpulkan bahwa arus kas operasi dan komponen akrual secara bersama tidak memiliki kemampuan lebih baik dalam memprediksi arus kas operasi masa depan. Dengan adanya tambahan informasi kualitas laba maka ditemukan hasil kualitas laba memperkuat prediksi arus kas operasi dan komponen akrual dalam memprediksi arus kas operasi masa depan.

Para pemakai laporan keuangan dapat mengevaluasi kemampuan perusahaan dalam menghasilkan kas dan setara kas lebih baik jika mereka mendapatkan informasi yang difokuskan pada earnings, perubahan posisi keuangan dan laporan arus kas perusahaan. Penelitian ini akan menguji kemampuan laba bersih, arus kas, perubahan piutang dan perubahan hutang dalam memprediksi arus kas di masa mendatang.

\section{KAJIAN PUSTAKA}

\section{Hubungan Logis Antar Variabel dan Perumusan Hipotesis}

\section{Hubungan Antara Kemampuan Laba bersih terhadap Prediksi Arus Kas Masa Depan}

Hubungan antara laba bersih dengan arus kas lebih jelas terlihat pada saat penyajian laporan arus kas, dimana menentukan arus kas bersih dari kegiatan operasi dengan menambahkan kembali atau mengurangkan laba bersih dari itemitem yang tidak berpengaruh terhadap kas. Yuwana dan Christiawan (2014), laba bersih berhubungan dengan arus kas, yang berarti bahwa laba bersih periode sekarang bisa memberikan informasi tentang arus kas perusahaan sekarang dan arus kas perusahaan di masa mendatang yang diharapkan. Kualitas laba yang tinggi memudahkan prediksi akurat tentang arus kas operasi di masa 
depan, karena laba bersih pada periode sekarang bisa memberiikan informasi tentang arus kas sekarang dan laba dengan kualitas yang tinggi dapat mencerminkan kelajutan laba dimasa depan. Vina dan Yulius (2014), laba bersih berpengaruh signifikan dan memiliki kemampuan untuk memprediksi arus kas masa depan terutama arus kas pada aktivitas operasi. Dengan demikian hipotesis pertama ini yaitu:

H1 : Diduga laba bersih secara parsial memiliki kemampuan yang dapat berpengaruh signifikan dalam memprediksi arus kas di masa depan.

\section{Hubungan Antara Kemampuan arus kas terhadap Prediksi Arus Kas Masa Depan}

Informasi arus kas historis sering digunakan sebagai indikator dari jumlah, waktu dan kepastian arus kas masa depan. Dahler dan Febrianto (2011), arus kas operasi tahun berjalan memiliki kemampuan lebih baik dari pada laba dalam memprediksi arus kas operasi masa depan baik untuk kelompok perusahaan berlaba positif maupun berlaba negatif. Yaniartha (2011), dengan tingkat keyakinan sebesar $95 \%$ dapat disimpulkan bahwa kemampuan prediktor arus kas dalam memprediksi arus kas satu tahun kedepan lebih baik dibandingkan dengan kemampuan prediktor arus kas terhadap laba. Joni (2011) meneliti daya prediksi laba dan aliran kas. Hasil penelitian menunjukkan aliran kas operasi sekarang terbukti memiliki kemampuan prediksi yang lebih baik dibandingkan laba terhadap aliran kas operasi di masa mendatang. Dengan demikian hipotesis kedua ini yaitu:

H2 : Diduga arus kas saat ini secara parsial memiliki kemampuan yang dapat berpengaruh signifikan dalam memprediksi arus kas di masa depan.

\section{Hubungan Antara Kemampuan Perubahan Piutang terhadap Prediksi Arus Kas Masa Depan}

Dalam praktiknya perusahaan melaporkan piutang sebesar nilai realisasi bersih jumlah piutang total dikurangi penyisihan piutang tak tertagih. Penilaian piutang sangat penting karena dampaknya terhadap posisi aktiva dan arus laba perusahaan. Perubahan piutang menunjukkan arus kas masa depan yang diharapkan berbeda dari arus kas masa kini, karena adanya pengumpulan jumlah dalam piutang saat ini. Penjualan yang dilakukan secara kredit akan menghasilkan peningkatan piutang dimana pengumpulan kas dilakukan beberapa waktu mendatang, oleh karena itu kenaikan penjualan kredit akan diikuti kenaikan atau perubahan dalam piutang dan aliran kas masuk setelah penjualan. Triyono (2011), menemukan bahwa dengan mempertimbangkan kualitas laba, perubahan piutang secara statistik signifikan sebagai prediktor arus kas di masa mendatang pada aktivitas operasi. Dengan demikian hipotesis ketiga ini yaitu:

H3 : Diduga perubahan piutang secara parsial memiliki kemampuan yang dapat berpengaruh signifikan dalam memprediksi arus kas di masa depan.

\section{Hubungan Antara Kemampuan Perubahan Hutang terhadap PrediksiArus Kas Masa Depan}

Kewajiban merupakan utang untuk mendapatkan pendanaan yang membutuhkan pembayaran di masa depan dalam bentuk uang, jasa dan aktiva lainya. Dasar penilaian yang digunakan adalah nilai sekarang pengeluaran kas/pengorbanan sumber ekonomi di masa mendatang untuk melunasi hutang tersebut sampai tanggal jatuh tempo. Perubahan hutang dihitung dari perubahan hutang lancar perusahaan. Perubahan hutang menunjukkan arus kas masa depan yang diharapkan 
berbeda dari arus kas saat ini karena adanya perubahan dalam jumlah pembayaran hutang saat ini. Dengan demikian arus kas masa depan juga diharapkan berbeda dari arus kas saat ini karena adanya pembayaran yang berkaitan dengan perubahan pembelian pada periode masa depan. Penelitian yang dilakukan oleh Triyono (2011), menemukan bahwa dengan mempertimbangkan kualitas laba, perubahan hutang secara statistik signifikan sebagai predictor arus kas di masa mendatang pada aktivitas operasi. Dengan demikian hipotesis keempat ini yaitu:
H4 : Diduga perubahan hutang secara parsial memiliki kemampuan yang dapat berpengaruh signifikan dalam memprediksi arus kas di masa depan.

\section{Kerangka Pemikiran Teoritis}

Dari penjelasan diatas, maka dapat dibuat kaitan antara kemapuan laba bersih, arus kas, perubahan piutang dan perubahan hutang terhadap arus kas masa depan dengan kerangka pemikiran sebagai berikut:

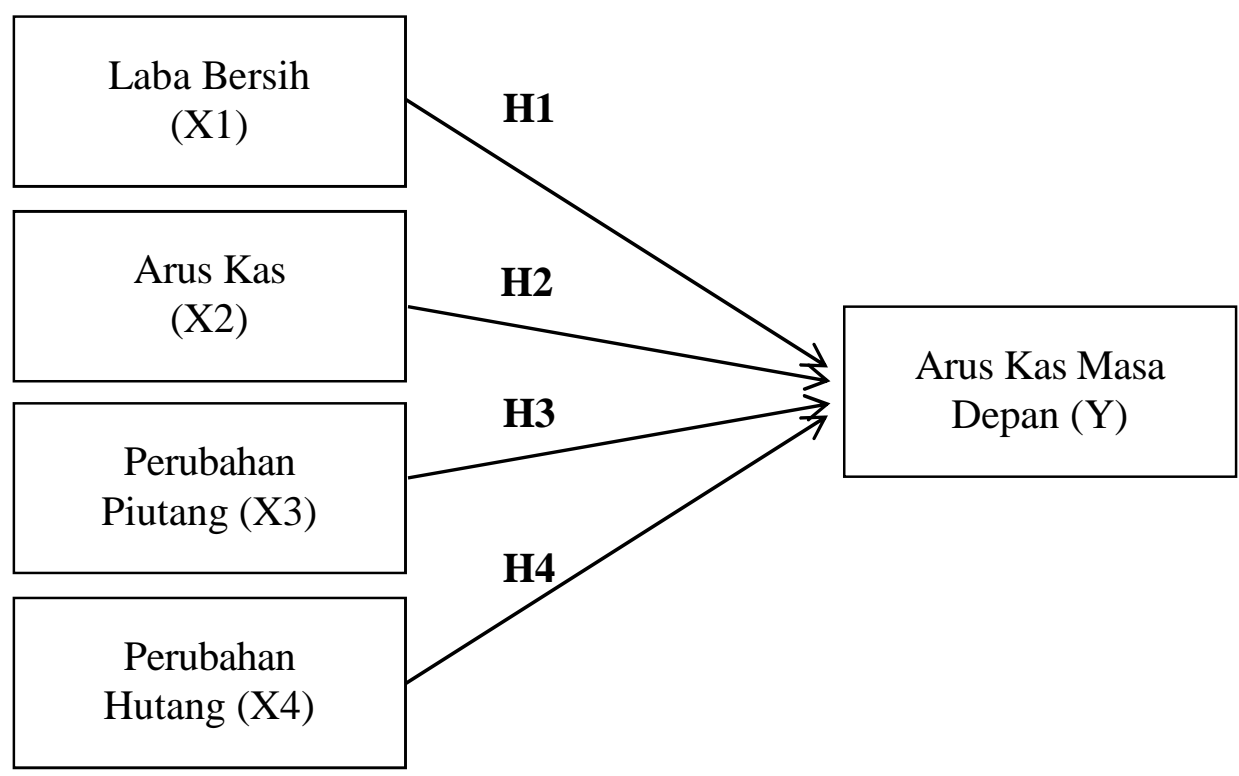

Gambar 1

Kerangka Pemikiran Teoritis

\section{METODE PENELITIAN}

\section{Definisi operasional dalam penelitian ini dapat dijelaskan sebagai berikut: \\ a. Arus Kas Masa Depan (Y)}

Arus kas yang digunakan dalam penelitian ini adalah total arus kas yang merupakan penjumlahan dari arus kas operasi, investasi dan pendanaan periode setelah tahun amatan $(\mathrm{t}+1)$. Arus kas masa depan diambil dari angka yang disajikan dalam Laporan Arus Kas tahun 2009 2013 pada perusahaan LQ 45 yang terdaftar di Bursa Efek Indonesia Tahun 2008 - 2012. Arus kas Masa Depan dirumuskan sebagai berikut :

$$
\mathrm{AK}=\mathrm{AK} t+1
$$




\section{b. Laba Bersih (X1)}

"Subramanyam dan Wild (2010), menyebutkan laba bersih adalah laba dari bisnis perusahaan yang sedang berjalan setelah bunga dan pajak", hal111. Laba bersih periode berjalan diperoleh dari laba sebelum pajak dikurangi dengan beban pajak. Angka laba bersih dapat diperoleh dari Laporan Laba Rugi Komprehensif dengan tahun amatan $(\mathrm{t})$, yaitu tahun 2008 - 2012 pada perusahaan LQ 45 yang terdaftar di Bursa Efek Indonesia. Laba bersih dirumuskan sebagai berikut :

LB = Laba Sebelum Pajak $(t)-$ Beban Pajak $(t)$

\section{c. Arus Kas (Cash Flow) (X2)}

Arus kas (Cash Flow) yang digunakan dalam penelitian adalah arus masuk dan arus keluar kas atau setara kas. Arus kas menjelaskan perubahan saldo kas dan setara kas pada awal dan akhir periode, rincian arus kas masuk dan keluar suatu entitas selama suatu periode tertentu. Arus kas diambil dari angka yang disajikan dalam Laporan Arus Kas tahun 2008 - 2012 pada perusahaan LQ 45 yang terdaftar di Bursa Efek Indonesia Tahun 2008 - 2012. Arus kas dirumuskan sebagai berikut :

$$
\mathrm{AK}=\mathrm{AK} t
$$

\section{d. Perubahan Piutang (X3)}

"Bachtiar (2010), Piutang (receivable) merupakan nilai jatuh tempo yang berasal dari penjualan barang atau jasa, atau dari pemberian pinjaman uang", hal 4.41. Piutang yang digunakan adalah piutang usaha perusahaan. Angka perubahan piutang usaha diperoleh dari perubahan piutang usaha pada dua periode $\left(\mathrm{PU}_{\mathrm{t}-\mathrm{PU}} \mathrm{t}-1\right)$. Perubahan piutang berasal dari Laporan Neraca (Laporan Posisi Keuangan) perusahaan tahun 2007 2012 pada perusahaan LQ 45 yang terdaftar di Bursa Efek Indonesia pada tahuan 2008 - 2012. Perubahan piutang dirumuskan sebagai berikut:

$\Delta$ PIUTANG $=$ Piutang $(t)-$ Piutang $(t-1)$

\section{e. Perubahan Hutang (X4)}

Hutang yang digunakan adalah hutang lancar perusahaan. Angka perubahan hutang lancar diperoleh dari perubahan hutang lancar pada dua periode (HLt- HLt1). Perubahan hutang berasal dari Laporan Neraca (Laporan Posisi Keuangan) perusahaan tahun 2007 - 2012 pada perusahaan LQ 45 yang terdaftar di Bursa Efek Indonesia pada tahun 2008 - 2012.

$\Delta$ HUTANG $=$ Hutang Lancar $(t)-$ Hutang Lancar $(t-1)$

\section{Populasi dan Sampel}

Populasi dalam penelitian ini adalah perusahaan LQ 45 yang tergabung di Bursa Efek Indonesia. Sampel penelitian ini diperoleh dengan metode purposive sampling, dengan kriteria perusahaan LQ 45 yang tergabung secara berturut-turut dalam periode 2008 -2012 serta menyajikan secara lengkap data yang dibutuhkan. Periode penelitian ini adalah selama 5 tahun, yaitu tahun 2008 2012 dengan menggunakan data laporan keuangan. Berdasarkan kriteria pengambilan sampel tersebut, maka jumlah sampel yang digunakan dalam penelitian ini ada 10 perusahaan.

\section{Jenis dan Sumber Data}

Data yang digunakan dalam penelitian ini adalah data sekunder. Data sekunder merupakan sumber yang tidak langsung memberikan data kepada pengumpul data, misalnya lewat orang lain atau lewat dokumen, (Soegiyono, 2012:187). Data sekunder yang digunakan dalam penelitian ini berupa laporan 
keuangan perusahaan LQ 45 dan Indonesian Capital Market Directory (ICMD) selama tahun 2007 - 2013 yang telah dipublikasikan. Sumber pengumpulan data sekunder dapat diperoleh dari database Bursa Efek Indonesia yang situs resminya yaitu www.idx.co.id.

\section{Metode Pengumpulan Data}

Metode pengumpulan data yang digunakan adalah metode dokumentasi, yaitu pengumpulan data melalui peninggalan tertulis, seperti arsip-arsip dan buku-buku tentang pendapat, teori, dalil atau hukum-hukum, dan lain-lain yang berhubungan dengan masalah penelitian (Margono, 2010, hal 181). Data yang berupa variabel laba bersih, arus kas (cash flow), perubahan piutang, dan perubahan hutang diperoleh dengan cara mencari data langsung dari catatan- catatan atau laporan keuangan yang ada pada Bursa Efek Indonesia.

\section{Teknik Analisis data}

\section{Uji Asumsi Klasik}

Untuk memenuhi syarat sebelum dilakukan uji hipotesis dan untuk menentukan ketepatan model maka perlu dilakukan pengujian atas beberapa asumsi klasik yang digunakan yaitu: uji normalitas, uji multikolinearitas, uji autokorelasi dan uji heteroskedastisitas.

\section{a. Uji Normalitas}

Uji normalitas residual yang digunakan adalah kolmogorovsemirnov. Jika signifikansi di bawah 0,05 berarti data tersebut tidak normal. sebaliknya jika signifikansi di atas 0,05 maka berarti data normal baku.

\section{b. Uji Multikolinearitas}

Untuk mendeteksi ada atau tidaknya multikolinearitas di dalam model regresi dapat dilihat dari nilai besaran korelasi antar variabel independen dan menggunakan hasil perhitungan Tolerance dan Variance Inflation Factor (VIF). "Ghozali $(2012,106)$ nilai tolerance yang rendah sama dengan nilai VIF tinggi (karena $\mathrm{VIF}=1 /$ Tolerance"). Nilai cutoff yang umum dipakai untuk menunjukkan adanya multikolonieritas adalah nilai Tolerance $\leq 0,10$ atau sama dengan nilai VIF $\geq 10$.

\section{c. Uji Autokorelasi}

Untuk mendeteksi gejala autokorelasi dapat menggunakan uji Durbin-Watson (D-W). Pengambilan keputusan ada tidaknya autokorelasi dapat dilihat dari ketentuan berikut (Singgih Santoso, 2014:194) :

- Bila nilai D-W terletak di bawah -2 berarti ada autokorelasi positif.

- Bila nilai D-W terletak diantara -2 sampai +2 berarti tidak ada autokorelasi.

- Bila nilai D-W terletak diatas +2 berarti ada autokorelasi negatif.

\section{d. Uji Heteroskedastisitas}

"Ghozali (2012) uji heteroskedastisitas bertujuan untuk menguji apakah dalam sebuah model regresi terjadi ketidaksamaan variance dari residual satu pengamatan ke pengamatan yang lain", hal 139. Salah satu uji statistik yang dapat digunakan untuk mendeteksi ada tidaknya heteroskedastisitas adalah Uji Park. Aturan keputusan uji Park adalah apabila nilai signifikansi masing-masing variabel dependen di atas tingkat kepercayaan 5\% maka tidak terjadi heteroskedastisitas. 


\section{HASIL DAN PEMBAHASAN}

\section{Statistik Deskriptif}

Berdasarkan data sampel yang bersumber dari laporan keuangan perusahaan tahun 2008-2012 diperoleh gambaran atau deskripsi dari suatu data yang dapat dilihat dari jumlah sampel, nilai minimum, nilai maksimum, nilai rata- rata, dan standar deviasi.

Berdasarkan tabel 1 dapat diketahui beberapa hal :

a. $\mathrm{N}$ adalah jumlah perusahaan yang digunakan dalam sampel penelitian dan data yang digunakan sebanyak 50 data.

b. Hasil statistik deskriptif ini menunjukkan rata-rata variabel Laba Bersih sebesar 5.360.509,02. Nilai minimum sebesar 313.751 milik Timah (Persero) Tbk. Nilai maksimum adalah 22.460.000 milik Astra International Tbk. Standard deviasi sebesar 5.658.411,8485 dimana standar deviasinya lebih besar dari nilai rata-ratanya, menunjukkan adanya fluktuasi nilai Laba Bersih yang besar pada perusahaan LQ 45 yang menjadi sampel.

c. Hasil statistik deskriptif ini menunjukkan rata-rata variabel Arus Kas sebesar 5.438.906,02. Nilai minimum sebesar 227.769 milik Astra Agro Lestari Tbk. Nilai maksimum adalah 15.157.522 milik Perusahaan Gas
Negara (Persero) Tbk. Standard deviasi sebesar 4.138.233,8661 dimana standar deviasinya lebih kecil dari nilai rata-ratanya, menunjukkan adanya fluktuasi nilai Arus Kas yang kecil pada perusahaan LQ 45 yang menjadi sampel.

d. Hasil statistik deskriptif ini menunjukkan rata- rata variabel Perubahan Piutang sebesar 444.268,86. Nilai minimum sebesar 1.085.110 milik Aneka Tambang (Persero) Tbk. Nilai maksimum adalah 5.135.000 milik Astra International Tbk. Standard deviasi sebesar 1.064.840,3392 dimana standar deviasinya lebih besar dari nilai rataratanya, menunjukkan adanya fluktuasi nilai Perubahan Piutang yang besar pada perusahaan LQ 45 yang menjadi sampel.

e. Hasil statistik deskriptif ini menunjukkan rata-rata variabel Perubahan Hutang sebesar 932.432,32. Nilai minimum sebesar -6.244.414 milik Telekomunikasi Indonesia (Persero) Tbk. Nilai maksimum adalah 12.296.000 milik Astra International Tbk. Standard deviasi sebesar 3.108.973,9666 dimana standar deviasinya lebih besar dari nilai rataratanya, menunjukkan adanya fluktuasi nilai Perubahan Hutang yang besar pada perusahaan LQ 45 yang menjadi sampel.

Tabel 1

Statistik Deskriptif

Descriptive Statistics

\begin{tabular}{|l|}
\hline \\
\hline Laba bersih \\
Arus kas \\
Perubahan Piutang \\
Perubahan Hutang \\
Arus Kas Masa \\
Valid N (listwise) \\
\hline
\end{tabular}

Std.

5.6584E

$4.1382 \mathrm{E}$

$1.0648 \mathrm{E}$

$3.1090 \mathrm{E}$

$4.9882 \mathrm{E}$

Sumber : Data Sekunder yang diolah 2014 
f. Hasil statistik deskriptif ini menunjukkan rata-rata variabel Arus Kas Masa Depan sebesar 6.327.493,228. Nilai minimum sebesar 227.769 milik Astra Agro Lestari Tbk. Nilai maksimum adalah 18.557.000 milik Astra International Tbk. Standard deviasi sebesar 4.988.159,7094 dimana standar deviasinya lebih kecil dari nilai rata-ratanya, menunjukkan adanya fluktuasi nilai Arus Kas Masa Depan yang kecil pada perusahaan LQ 45 yang menjadi sampel.

\section{Uji Asumsi Klasik}

Penelitian ini menggunakan model regresi linier berganda. Model regresi yang baik disyaratkan harus memenuhi tidak adanya masalah asumsi klasik. Uji asumsi klasik dari masing-masing model adalah sebagai berikut :

\section{Uji Normalitas}

Uji statistik lain yang dapat digunakan untuk menguji normalitas residual dalam penelitian kali ini adalah pengujian dengan menggunakan uji Kolmogorov Smirnov. Dari hasil uji normalitas besarnya Kolmogorov Smirnov adalah 0.914 dan signifikansi pada 0,373. Karena hasil signifikansi sebesar 0,373 > 0,05 dapat disimpulkan bahwa distribusi data dalam penelitian ini berdistribusi normal.

\section{Uji Multikolinieritas}

Dari hasil uji multikolinearitas menunjukkan nilai tolerance masingmasing variabel bebas berada di atas 0,1, sedangkan pada nilai VIF masing-masing variabel bebas di bawah 10 artinya bahwa variabel-variabel penelitian tidak menunjukkan adanya gejala multikolinieritas dalam model regresi.

\section{Uji Heteroskedastisitas}

Bertujuan untuk menguji apakah dalam model regresi terjadi ketidaksamaan varian residual antara yang satu dengan yang lain. Selain pengujian heteroskedastisitas dilakukan dengan menggunakan scatterplot juga dapat dilakukan dengan Uji Park yaitu dengan meregres kuadrat residual sebagai variabel dependen dengan variabel independen. Aturan keputusan uji Park adalah apabila nilai signifikansi masing-masing variabel dependen di atas tingkat kepercayaan 5\% maka tidak terjadi heteroskedastisitas. Hasil Uji Park diketahui bahwa nilai signifikansi kelima variabel bebas lebih dari 0,05. Dengan demikian dapat disimpulkan bahwa tidak terjadi heteroskedastisitas pada model regresi.

\section{Uji Autokorelasi}

Hasil dari perhitungan SPSS menunjukkan nilai Durbin-Witson sebesar 1,874 yang terletak diantara -2 sampai +2 sehingga bebas dari gangguan autokorelasi.

\section{Analisis Regresi Liniear}

Dari tabel 2 dapat dibentuk rumus persamaan sebagai berikut :

$\mathbf{Y}=\mathbf{a}+\boldsymbol{B}_{1} \mathbf{X}_{1}+\boldsymbol{B}_{2} \mathbf{X}_{2}+\boldsymbol{B}_{3} \mathbf{X}_{3}+\boldsymbol{B}_{4} \mathbf{X}_{4}+\mathrm{e}$

Dengan rumus persamaan diatas, maka dapat kita buat hasil persamaan sebagai berikut :

Arus Kas Masa Depan $=\mathbf{3 9 2 . 8 1 0 , 6 5 3}+$ 0,249 Laba Bersih + 0,91 Arus Kas 0,704 Perubahan Piutang - 0,041 Perubahan Hutang + e

Dari persamaan regresi tersebut diatas, maka dapat di jelaskan bahwa :

- $\mathrm{a}=$ konstanta (nilai mutlak Y) apabila Laba Bersih, Arus Kas, Perubahan Piutang dan Perubahan Hutang $=0$, maka Arus Kas Masa Depan sebesar $392.810,653$. 
Tabel 2

Hasil Analisis Regresi Berganda

Coefficients $^{\mathrm{a}}$

\begin{tabular}{|c|c|c|}
\hline \multirow[b]{2}{*}{ Model } & \multicolumn{2}{|c|}{$\begin{array}{l}\text { Unstandardi } \\
\text { zed }\end{array}$} \\
\hline & B & St \\
\hline 1 (Constant) & $\begin{array}{l}3928 \\
10.6\end{array}$ & $\begin{array}{l}51 \\
54\end{array}$ \\
\hline Laba bersih & .249 & .08 \\
\hline Arus kas & .910 & .10 \\
\hline Perubahan & -.704 & .41 \\
\hline $\begin{array}{l}\text { Piutang } \\
\text { Dependent Vari }\end{array}$ & $\begin{array}{r}-.041 \\
\text { Kas } 1\end{array}$ & .13 \\
\hline
\end{tabular}

$$
\begin{aligned}
& \text { Stan } \\
& \text { dard } \\
& \text { B } \\
&
\end{aligned}
$$$$
\left|\begin{array}{c}
\text { Colline } \\
\text { arity } \\
\text { To } \\
\\
\end{array}\right| \begin{array}{c|}
.41 \\
.52 \\
.50 \mid \\
.53 \mid
\end{array} \mid
$$

Sumber : Data Sekunder yang diolah 2014

- $\beta_{1}=$ koefisien regresi Laba Bersih sebesar 0,249 yang berarti bahwa nilai koefisien regresi positif menunjukkan pengaruh yang ditimbulkan searah, dimana naiknya variabel Laba Bersih sebesar 1 satuan berpengaruh pada peningkatan variabel Arus Kas Masa Depan sebesar 0,249 satuan.

- $\beta_{2}=$ koefisien regresi Arus Kas sebesar 0,91 yang berarti bahwa nilai koefisien regresi positif menunjukkan pengaruh yang ditimbulkan searah, dimana naiknya variabel Arus Kas sebesar 1 satuan berpengaruh pada peningkatan variabel Arus Kas Masa Depan sebesar 0,91 satuan.

- $\beta_{3}=$ koefisien regresi Perubahan Piutang sebesar -0,704 yang berarti bahwa nilai koefisien regresi negatif menunjukkan pengaruh yang ditimbulkan tidak searah, dimana naiknya variabel Perubahan Piutang sebesar 1 satuan berpengaruh pada penurunan variabel Arus Kas Masa Depan sebesar 0,704 satuan.

- $\beta_{4}=$ koefisien regresi Perubahan Hutang sebesar $-0,041$ yang berarti bahwa nilai koefisien regresi negatif

\begin{abstract}
menunjukkan pengaruh yang ditimbulkan tidak searah, dimana naiknya variabel Perubahan Hutang sebesar 1 satuan berpengaruh pada penurunan variabel Arus Kas Masa Depan sebesar 0,041 satuan.
\end{abstract}

\section{Pengujian Hipotesis}

\section{Uji Parsial ( Uji t )}

Untuk menentukan nilai $\mathrm{t}$ tabel digunakan tingkat signifikan $\alpha=5 \%: 2$ $=2,5 \%$ (uji 2 sisi) dengan derajat kebebasan (degree of freedom ) df $=(n-k-$ 1) dimana $n$ adalah jumlah observasi dan $\mathrm{k}$ adalah jumlah variabel independen dengan kriteria uji adalah $: 3$

Ho diterima bila : $t_{\text {hitung }}<t_{\text {tabel }}$ atau $t_{\text {hitung }}>-t_{\text {tabel }}$ dengan signifikan $>0,05$

Ho ditolak bila : $\quad t_{\text {hitung }}>t_{\text {tabel }}$ atau $-t_{\text {hitung }}<-t_{\text {tabel }}$ dengan signifikan $<$ 0,05

a. Pengujian $\mathrm{H}_{1}$ : Uji pengaruh parsial (uji t) antara variabel Laba Bersih terhadap Arus Kas Masa Depan.

Hasil perhitungan dengan mengguna- 
kan SPSS dapat diketahui bahwa nilai $t_{\text {hitung }}=2,916$ lebih besar dari $t_{\text {tabel }}=$ 2,014 dan nilai signifikan sebesar 0,006 lebih kecil dibandingkan dengan taraf signifikansi $\alpha=5 \%=0,05$, artinya ada pengaruh yang signifikan antara Laba Bersih terhadap Arus Kas Masa Depan secara parsial. H1 dapat diterima.

b. Pengujian $\mathrm{H}_{2}$ : Uji pengaruh parsial (uji t) antara variabel Arus kas terhadap Arus Kas Masa Depan.

Hasil perhitungan dengan menggunakan SPSS diketahui bahwa nilai $t_{\text {hitung }}$ $=8,730$ lebih besar dari $t_{\text {tabel }}=2,014$ dan nilai signifikan sebesar 0,000 lebih kecil dibandingkan dengan taraf signifikansi $\alpha=5 \%=0,05$, artinya ada pengaruh yang signifikan antara Arus Kas terhadap Arus Kas Masa Depan secara parsial. H2 dapat diterima.

c. Pengujian $\mathrm{H}_{3}$ : Uji pengaruh parsial (uji t) antara variabel Perubahan Piutang terhadap Arus Kas Masa Depan.

Hasil perhitungan dengan menggunakan SPSS diketahui bahwa nilai $t_{\text {hitung }}$ $=-1,712$ lebih besar dari $t_{\text {tabel }}=$ 2,014 dan nilai signifikan sebesar 0,094 lebihbesar dibandingkan dengan taraf signifikansi $\alpha=5 \%=0,05$, artinya tidak ada pengaruh yang signifikan antara Perubahan Piutang terhadap Arus Kas Masa Depan secara parsial. H3 ditolak.

d. Pengujian $\mathrm{H}_{4}$ : Uji pengaruh parsial (uji t) antara variabel Perubahan Hutang terhadap Arus Kas Masa Depan.

'Hasil perhitungan dengan menggunakan SPSS diketahui bahwa nilai $t_{\text {hitung }}$ $=-0,296$ lebih besar dari $t_{\text {tabel }}=-$ 2,014 dan nilai signifikan sebesar 0,769 lebih besar dibandingkan dengan taraf signifikansi $\alpha=5 \%=$ 0,05 , artinya tidak ada pengaruh yang signifikan antara Perubahan Hutang terhadap Arus Kas Masa Depan secara parsial. H4 ditolak.

Hasil perhitungan menunjukkan bahwa besarnya nilai Adjusted R Square adalah 0,808 . Hal ini berarti $80,8 \%$ variasi intensi Arus kas Masa Depan dapat dijelaskan oleh variasi dari keempat variabel independen yaitu Laba Bersih, Arus Kas, Perubahan Piutang dan Perubahan Hutang. Sedangkan sisanya sebesar 19,2\% (100\%-80,8\%) dijelaskan oleh sebab-sebab yang lain di luar model.

\section{Uji Determinasi ( $\mathbf{R}^{2}$ )}

Tabel 10

Hasil Koefisien Determinasi $\left(\mathbf{R}^{2}\right)$ Model Summary ${ }^{b}$

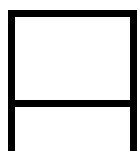

\begin{tabular}{l|}
$\mathrm{R}$ \\
.90
\end{tabular}
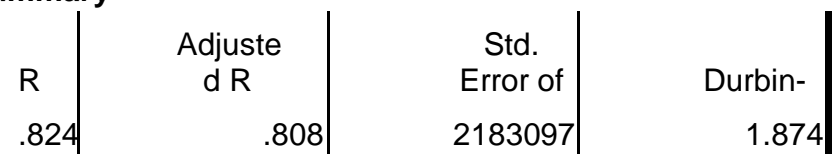

a. Predictors: (Constant), Perubahan Hutang, Arus kas, Perubahan Piutang, Laba bersih

b. Dependent Variable: Arus Kas Masa Depan 


\section{Pembahasan}

\section{Pengaruh Laba Bersih terhadap Arus Kas Masa Depan}

Hasil perhitungan diperoleh bahwa ada pengaruh yang signifikan antara Laba Bersih terhadap arus kas masa mendatang secara parsial. Hasil ini membuktikan bahwa laba bersih berhubungan dengan arus kas, yang berarti bahwa laba bersih periode sekarang bisa memberikan informasi tentang arus kas perusahaan sekarang dan arus kas perusahaan di masa mendatang yang diharapkan. Maka jika laba bersih lebih besar dari yang diperkirakan, maka arus kas sekarang juga akan lebih besar dari yang diperkirakan dan rata-rata probabilitas arus kas di masa mendatang akan meningkat. Kualitas laba yang tinggi memudahkan prediksi akurat tentang arus kas operasi di masa depan, karena laba bersih pada periode sekarang bisa memberikan informasi tentang arus kas sekarang dan laba dengan kualitas yang tinggi dapat mencerminkan kelajutan laba dimasa depan.

Hal ini didukung oleh penelitian yang dilakukan Dahler dan Febriyanto (2006), Christiawan dan Yuwana (2014), Ferra (2012) dan Wartini (2013) yang mengatakan Laba Bersih berpengaruh terhadap Arus Kas Masa Depan.

\section{Pengaruh Arus Kas terhadap Arus Kas Masa Depan}

Hasil perhitungan diperoleh bahwa ada pengaruh yang signifikan antara arus kas terhadap arus kas masa mendatang secara parsial. Hasil penelitian ini sesuai dengan teori menurut PSAK No.2 arus kas yang berasal dari aktivitas operasi merupakan akitivitas penghasil utama pendapatan perusahaan dan dapat memberikan informasi yang memungkinkan para pengguna untuk mengevaluasi perubahan dalam asset bersih entitas, struktur keuangan (termasuk likuiditas dan solvabilitas) dan kemampuan untuk mempengaruhi jumlah serta waktu arus kas operasi.

Penelitian ini didukung oleh penelitian yang dilakukan oleh Dahler dan Febriyanto (2006), Christiawan dan Yuwana (2014), Ferra (2012), Rispayanto (2013), Meliana (2011), Ramon (2013) yang menyatakan bahwa Arus Kas berpengaruh terhadap Arus Kas Masa Depan.

\section{Pengaruh Perubahan Piutang terhadap Arus Kas Masa Depan}

Hasil perhitungan diperoleh bahwa tidak ada pengaruh yang signifikan antara perubahan piutang terhadap arus kas masa mendatang secara parsial. Hasil ini menjelaskan bahwa besarnya piutang yang ada pada periode berjalan tidak secara langsung memberikan andil yang besar pada perubahan arus kas masa mendatang. Hal ini disebabkan karena nampaknya beberapa piutang yang dimiliki perusahaan pada satu periode merupakan piutang dalam jangka waktu yang tidak hanya dapat tertagih selama satu tahun ke depan, namun bisa pada beberapa tahun ke depan, sehingga efek piutang terhadap arus kas masa mendatang menjadi tidak nyata, juga pemberian cashback atau program promosi penjualan yang seringkali dicatat dalam bentuk akrual.

Penelitian ini didukung oleh Triyono (2011) yang menyatakan bahwa Perubahan Piutang tidak memiliki kemampuan yang lebih baik terhadap Arus Kas Masa Depan.

\section{Pengaruh Perubahan Hutang terhadap Arus Kas Masa Depan}

Hasil perhitungan diperoleh bahwa tidak ada pengaruh yang signifikan antara perubahan hutang terhadap arus kas masa mendatang secara parsial. Hasil ini menjelaskan bahwa besarnya hutang yang ada pada periode berjalan tidak secara langsung memberikan andil 
yang besar pada perubahan arus kas masa mendatang. Hal ini disebabkan karena nampaknya beberapa hutang yang dimiliki perusahaan pada satu periode merupakan hutang dalam jangka waktu yang tidak hanya dapat tertagih selama satu tahun ke depan, namun bisa pada beberapa tahun ke depan, sehingga efek hutang terhadap arus kas masa mendatang menjadi tidak nyata, namun seringkali dicatat dalam bentuk akrual.

Penelitian ini didukung oleh Triyono (2011) yang menyatakan bahwa Perubahan Hutang tidak memiliki kemampuan yang lebih baik terhadap Arus Kas Masa Depan.

\section{SIMPULAN}

Berdasarkan penelitian yang telah dilakukan maka dapat disimpulkan sebagai berikut:

1. Laba Bersih dan Arus Kas memiliki pengaruh signifikan terhadap Arus Kas Masa Mendatang, sedangkan Perubahan Piutang dan Perubahan Hutang tidak mempunyai pengaruh secara signifikan terhadap Arus Kas Masa Depan.

2. Hasil pengujian koefisien determinasi $\left(\mathrm{R}^{2}\right)$ menunjukkan nilai sebesar 0,808. Hal ini berarti varians Laba Bersih, Arus Kas, Perubahan Piutang dan Perubahan Hutang sebesar 80,8 \% . Sedangkan sisanya yaitu sebesar $19,2 \%$ dijelaskan oleh faktor- faktor lain.

3. Bagi Investor, hasil penelitian ini dapat digunakan sebagai salah satu pertimbangan dalam melakukan keputusan investasi dalam rangka mengurangi risiko dari investasi tersebut, investor dapat menjadikan laba bersih dan arus kas operasi dalam memprediksi arus kas di masa mendatang.

4. Bagi Perusahaan, pihak perusahaan harus dapat meyakinkan para investor dengan meningkatkan kinerja perusahaan yang baik agar memperoleh laba yang tinggi, sehingga investor akan tertarik atau berminat untuk menanamkan sahamnya di perusahaan tersebut.

Agenda Penelitian Yang Akan Datang

Berdasarkan hasil penelitian ini, dapat diberikan beberapa agenda untuk penelitian yang akan datang sebagai berikut:

1. Untuk penelitian selanjutnya hendaknya menggunakan periode penelitian yang lebih lama.

2. Hendaknya menggunakan sampel perusahaan dari seluruh populasi yang terdaftar di BEI agar diperoleh sampel yang lebih baik sesuai dengan data yang diinginkan

3. Penelitian selanjutnya sebaiknya menggunakan laba bersih setelah pajak.

\section{DAFTAR PUSTAKA}

Bachtiar, Yanivi. 2010. Analisis Informasi Keuangan, Edisi 1. Jakarta: Universitas Terbuka

Dahler dan Febrianto. 2006. "Kemampuan Prediktif Earnings Dan Arus Kas Dalam Memprediksi Arus Kas Masa Depan”, Jurnal Simposium Nasional Akuntansi IX Padang, 23-26 Agustus 2006

Ferra. 2012. "Kemampuan Laba Bersih, Arus Kas Operasi, dan Rasio Piutang untuk Mempengaruhiarus Kas Masa Mendatang Pada Perusahaan Food And Beverage di BEI", Jurnal Ilmiah Mahasiswa Akuntansi, Vol. 1, No. 3 
Ghozali dan Chariri. 2007. Teori Akuntansi, Edisi 3. Semarang: Universitas Diponegoro

Ghozali, Imam. 2012. Aplikasi Analisis Multivariate dengan Program SPSS, Edisi 6. Semarang: BP Universitas Diponegoro

Harahap, Sofyan. 2013. Analisis Kritis Atas Laporan Keuangan. Jakarta: Rajagrafindo Perkasa

Ikatan Akuntan Indonesia. 2009. Pernyataan Standar Akuntansi Keuangan No 1, Penyajian Laporan Keuangan

Ikatan Akuntan Indonesia. 2009. Pernyataan Standar Akuntansi Keuangan No 2, Penyajian Laporan Arus Kas

Joni. 2011. "Daya Prediksi Laba dan Aliran Kas (Studi Empiris pada Perusahaan Manufaktur di Bursa Efek Indonesia Periode 20052009)", Jurnal Reviu Akuntansi dan Keuangan, Vol. 1, No.1

Kartikahadi et.al. 2012. Akuntansi Keuangan berdasarkan SAK berbasis

IFRS, Buku 1. Jakarta: Salemba Empat

Margono. 2010. Metodologi Penelitian Pendidikan. Jakarta: Rineka Cipta

Meliana dan Indrawati. 2012. "Kemampuan Laba dan Arus Kas Memprediksi Arus Kas Menggunakan Partial Adjustment Model", Jurnal Universitas Binus

Nazir. 2011. Metopel Penelitian. Bogor: Ghalia Indonesia
Nany, Magdalena. 2013. "Analisis Kemampuan Prediksi Arus Kas Operasi", Jurnal Dinamika Akuntansi, Vol. 5, No.1

Ramon, Kostia. 2013. "Pengaruh Kemampuan Prediktif Laba Dan Arus Kas Operasi Dalam Memprediksi Arus Kas Operasi Masa Depan", Jurnal Fakultas Ekonomi Universitas Negeri Padang

Rispayanto, Shofiahilmy. 2013. "Pengaruh Laba Kotor, Laba Operasi, Laba Bersih dan Arus Kas Operasi Dalam Memprediksi Arus Kas Operasi Masa Mendatang", Jurnal Fakultas Ekonomi Universitas Negeri Padang

Subramanyam dan Wild. 2010. Analisis Laporan Keuangan, Buku 1. Jakarta: Salemba Empa

Santoso, Singgih. 2014. Statistik Parametrik: Konsep dan Aplikasi dengan SPSS (Edisi Revisi). Jakarta: Elex Media Komputindo

Soegiyono.2012. Metode Penelitian Kuantitatif Kualitatif dan R\&D. Bandung: Alfabeta

Triyono. 2011. "Dampak Kualitas Laba Terhadap Kemampuan Prediksi Laba, Arus Kas, Dan Komponen Akrual", Jurnal Simposium Nasional Akuntansi XIV Aceh, 21-22 Juli 2011

Wartini. 2013. "Pengaruh Laba Kotor, Laba Operasi Dan Laba Bersih Dalam Memprediksi Arus Kas Aktivitas Operasi Di Masa Mendatang". Jurnal Fakultas 
Ekonomi Universitas Maritim Raja Ali Haji

Yuwana dan Jogi. 2014. "Analisa Kemampuan Laba Dan Arus Kas Operasi dalam Memprediksi Arus Kas Operasi Masa Depan”, Jurnal Business Accounting Review, Vol.2, No.1

.Darwanto,

Aki.

"SignallingTheory".

http://www.wanto.web.id/2008/10/

signalling theory.html.wanto'sBlog

.Hidayat, Anwar. 'Transformasi Data".

http://www.statistikian.blogspot.co $\mathrm{m} / 2013 / 01 /$ transformasi-data.html

.Kabo, Muslim.'Teori Manajemen Keuangan, Pemasaran, Perbankan dan SDM". http://ekonomi.kabo.biz/2011/07/te ori-sinyal.html

"Laporan Keuangan Arus Kas”. 21 Juli 2010. http://www.blogdeta.blogspot.com/ 2010/07/laporan-keuangan-aruskas. Html

."Laporan Keuangan dan Tahunan". http://www.idx.co.id/idid/beranda/ perusahaantercatat/laporankeuang andantahunan.aspx

."LQ 45 Di Bursa Efek Indonesia". http://www.sahamok.com/bei/lq45/

."LQ 45". http://www.idx.co.id/idid/beranda/publikasi/lq45.aspx

.Muhayatsyah, Ali. "Hubungan Pemegang Saham Dengan Perusahaan Pada Pembagian
Deviden". https:// www.academia.edu/1260404/Menc ermatiHubunganPemengangSaha mdenganPerusahaanPadaPembag ianDividen

.Panga, Mujiharto. "Konsep Hutang". $07 \quad$ Januari 2014. http://mujihartopanga.blogspot.co m/2014/01/konsep-hutang.html

.Redaksi Selasar. "Dampak Pemilu Bagi Pertumbuhan Ekonomi”. 19 Maret 2014. https://www.selasar.com/ekonomi/ dampak-pemilu-bagi-pertumbuhan -ekonomi.html

.Riyandi, Saugy. "Laba Bersih Anjlok, PTBA Janji Tak Pecat Karyawan". 26 Juli 2013. http://www.merdeka.com/uang/lab a-bersih-anjlok-ptba- janji-takpecat-karyawan.html 